\section{Helpline for giant clams}

SIR-Hundreds, possibly thousands, of giant clams (Tridacna sp.) are being cultured commercially in the Caribbean, possibly without any screening for diseases. To our knowledge, more than 600 specimens are being cultured in Bonaire, others in Guadeloupe and in south Florida, and there are unconfirmed reports of other projects in the Caribbean and of planned exhibitions in north Florida and Arizona. The Florida and Bonaire clams are from Palau, Micronesia. We do not know if any of these animals have been tested for pathogens.

We would like to get in touch with all those rearing giant clams in the Atlantic so that we can arrange proper disease screening. There is an urgent need to avoid introducing pathogens which may harm the conduct and reputation of aquaculture or damage Caribbean fisheries. In advocating testing, we do not condone the introduction of Tridacna sp. outside their previous natural ranges, but take a practical approach in an attempt to minimize possible damage.

Several projects in the Pacific are attempting to rear Tridacna sp. for their economically valuable adductor muscle, mantle tissue and shells ${ }^{1}$. However desirable giant clams may be, their diseases, once introduced, may not be easy to eliminate: pathogens accompanying introduced organisms represent an uncontrollable experiment. The most serious pathogen known to occur in Tridacna sp. is a Perkinsus species, apicomplexan, which has caused mass mortal- ities $^{2.3}$, and which, alarmingly, seems to possess little host specificity ${ }^{2}$. This genus causes death and disease in bivalves world-wide $^{24}$. Guidelines to prevent the transfer of various microbial associates have been accepted by some of those who distribute and culture these clams in the Pacific (C. E. Birkeland and L. G. Eldredge, personal communication).

Our Caribbean Aquatic Animal Health Project (telephone number 809899 2048) does not have the authority to prohibit introduction or to certify disease-free stocks of Tridacna sp., but we do seek to establish cooperation between those who are holding these animals in the Atlantic and those working on their biology and diseases. We would be grateful for any information that would help us to locate the Atlantic projects, to arrange for disease screening if necessary, and to help control any disease problems which may arise.

ERNEST H. WILLIAMS JR LUCY BUNKLEY-WILLIAMS

Caribbean Aquatic Animal Health Project, Department of Marine Sciences,

University of Puerto Rico,

PO Box 908,

Lajas,

Puerto Rico 00667-0908, USA

1. Braley, R.D. World Aquaculture 20, 6-17 (1988)

2. Goggin, C. L. \& Lester, R. J. G. Proc. 6th int. Coral Reef Symp. Abstr. 36 (1988).

3. Alder, J. \& Braley, R.D. Austr. J. mar. Freshwater Res. (in the press).

4. Williams, E.H., Jr \& Bunkley-Williams, L. Atoll Res. Bull. 335. 1-71 (1990).

\title{
Cytoskeletal similarities
}

SIR-M. Way and A. Weeds in their News and Views article (Nature 344, 292; 1990) suggest that yeast has a simpler cytoskeletal system, lacking redundancy at the gene level, compared with that in the slime mould Dictyostelium. But there are at least two lines of evidence indicating that the yeast cytoskeletal network behaves as a parallel distributed processor, as has been considered by D. Bray and J. Vasiliev in their News and Views article on cytoskeleton functioning in the locomotion of Dictyostelium amoebae (Nature 338, 203; 1989).

First, the SPA2 protein of the yeast Saccharomyces cerevisiae (M. Snyder, J. Cell Biol. 108, 1419; 1989) is associated with actively growing regions of the cell surface. Mutants display either a slightly altered budding pattern (increased numbers of non-axially budding cells) or an inability to stop growing under nutrient-limiting conditions which often results in multiple budding.

Second, a strain containing the null allele for the actin-binding protein SAC1 (P. Novick et al. Genetics 121, 659; 1989),

\section{Pheasant spurs out of fashion}

SIR-The report of female pheasants preferring males with longer spurs ${ }^{1}$ and the comments thereon $^{2-4}$ prompt me to communicate briefly my findings in British pheasants, obtained from experiments performed in May and June 1988. These birds showed no female preference for longer spurs at all.

The mate-choice pen consisted of a

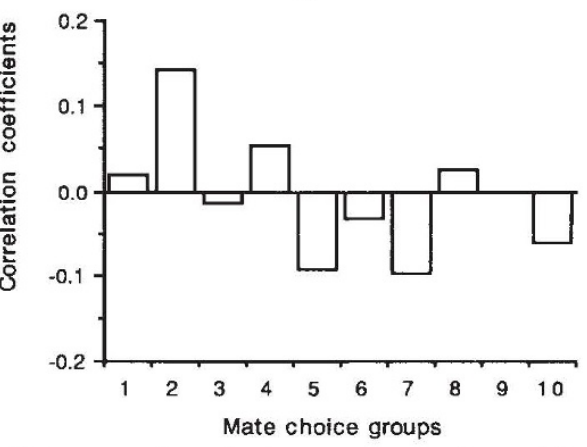

Male spur length does not correlate with female choice. The figure shows correlation coefficients for a simple regression of female preference within each group.

square enclosure 15 metres by 15 metres, with a 3-metre-long oval-shaped pen built into each side to hold the males. I used 40 non-related males and 40 females, and performed 10 separate trials, each consisting of four males and two pairs of females. All the birds were 1 year old, and the males had been kept in separate pens for 3 months before the trials. The females had not had previous experience of adult male pheasants. I measured female preference by the number of females who solicited copulations from each male in a trial. I also measured this parameter by the proportion of time each female spent within 1 metre of each male.

There was considerable variation in male spur length (not including tarsus width) with the mean at 9.2 millimetres (range 0-12.5 millimetres, standard deviation 2.145). But association of female copulation solicitation with spur length is not significant $(P=0.8183 ; N=40$; correlation coefficient $=0.003$; standard errror $=0.013$; see figure). Female preference for spur length, as measured by female proximity within 1 metre of a male was also not significant, but the pattern was different from that of choice measured by copulation solicitations.

Von Schantz et al. ${ }^{2}$ measured female preference as females less than 100 metres from a male. I suggest that females could benefit from spending time near a longspurred male when feeding to obtain the most protection from non-territorial males and predators. Females are known to be considerably less vigilant when in the presence of a male ${ }^{5}$, and perhaps can afford to be more so if they know the male
Department of Botany,

University of Helsinki,

Unioninkatu 44,

00170 Helsinki,

Finland 